\title{
MODERN INNOVATIVE PEDAGOGICAL TECHNOLOGIES IN TEACHING ECOLOGY AT THE EDUCATIONAL ESTABLISHMENTS
}

\author{
Makhmatkulova Z. Kh \\ Associate Professor, TSPU Named After Nizami, Uzbekistan \\ Makhmatkulov I. Kh \\ Ecology Teacher Tashkent Regional Branch of The Samarkand Veterinary Medical Institute, Uzbekistan
}

\section{ABSTRACT}

The article deals with the ecological problems, its content, meaning, types of environmental problems, and ecological education of the younger generation.

KEYWORDS:- Ecology, environment, nature, purity, globe, distractions, volcanoes, nature, education, existence, solid, continents, etc.

\section{INTRODUCTION}

Our mother earth is currently facing a lot of environmental concerns. The environmental problem like global warming, acid rain, air pollution, urban sprawl, waste disposal, ozone layer depletion, water pollution, climate change and many more affect every human, animals, creature and nation on this planet. Once the earth was a solid one, it was surrounded with water. The nature showed its influence to the globe. The globe suffered from different distractions, volcanoes, at the result of those changes the earth divided into continents. From that time the human influence changed the nature's purity existence, began ecological problem.

Ecology: a science that deals with the relationships between groups of living things and their environments.

The relationships between a group of living things and their environments.

Environment: the conditions that surround someone or something.

The conditions and influences that effect the growth, health, progress, etc, of someone or something.

\section{The natural world.}

\section{Full Definition. Plural ecologies}

1. A branch of science concerned with the interrelationships of organisms and their environments.

2. The totality or pattern of relations between organisms and their environment. 
CURRENT RESEARCH JOURNAL OF PEDAGOGICS 2(11): 71-75, November

2021 DOI: https://doi.org/10.37547/pedagogics-crjp-02-11-15

ISSN 2767-3278

(C)2021 Master Journals

\section{Crossref doi) 81 Google}

Accepted 25th November, 2021 \& Published 30 ${ }^{\text {th }}$ November, 2021

3. Human ecology.

4. Environment, climate-the moral ecology; also: an often delicate or intricate system or complex- the ecology of language.

\section{Full Definition.}

1: The circumstances, objects, or conditions by which one is surrounded.

2. a: the complex of physical, chemical, and biotic factors ( such as climate, soil, and living things) that act upon an organism or an ecological community and ultimately determine its form and survival.

B: the aggregate or social and cultural condition that influence the life of an individual or community.

3: the position or characteristic position of a linguistic element in a sequence.

4: a computer interface from which various tasks can be performed- a programming environment.

Examples. He grew up in a loving environments. We are trying to create a better business environments.

These animals were raised in a controlled environment.

Types of ecology. What are the different types of ecology? the different types of ecology includemolecular ecology, organismal ecology, pollution ecology, community ecology, global ecology, landscape ecology and ecosystem ecology.

What are the 3 types of ecology?- Ecology is the branch of science that examines the relationships organisms have to each other and to their environment. Scientists who study those relationships are called ecologists. There are many different ways to study ecology. Some types are landscape ecology, population ecology, and behavioral ecology .

Types of ecology/ National Geographic Society.
Types of ecology- microbial ecology. Microbial ecology looks at the smallest fundamental levels of life, that is the cellular level.

- $\quad$ Organism/ Behavioral Ecology .......

- $\quad$ Population Ecology.....

- $\quad$ Community Ecology....

- $\quad$ Ecosystem Ecology....

- Global Ecology ( biosphere).

What are the contents of ecosystem ?

Ecosystems contain biotic or living parts, as well as abiotic factors, or nonliving parts. Biotic factors include plants, animals, and other organisms. Abiotic factors include rocks, temperature, and humidity. Every factor in an ecosystem depends on every other factor, either directly or indirectly.

What are the basic issues of environmental education ? - one of the problems related to Environmental Education is the lack of proper training of the teacher, subject. It calls for unprecedented collaboration in teaching which is difficult to achieve practically. Facilities, but in ASSAM there is a dearth of these facilities.

Environmental education is a process that allows individuals to explore environmental issues, engage in problem solving, and take action to improve the environment. As a result, individuals develop a deeper understanding of environmental issues, and have the skills to make informed and responsible decisions.

The components of environmental education are :

- Awareness and sensitivity to the environmental challenges;

- Knowledge and understanding of the environment and environmental challenges;

- $\quad$ Attitudes of concern for the environment 
and motivation to improve or maintain environmental quality;

- Skills to identify and help resolve environmental challenges;

- Participation in activities that lead to the resolution of environmental challenges.

Environmental education does not advocate a particular viewpoint or course of action. Rather, environmental education teachers individuals how to weigh various sides of an issue through critical thinking and it enhances their own problem-solving and decision-making skills.

The national Environmental Education Act of 1990 requires EPA to provide national leadership to increase environmental literacy. EPA established the Office of implement this program.

Environmental Education

- Increases public awareness and knowledge of environmental issues;

- $\quad$ Does teach individuals critical thinking;

- $\quad$ Does enhance individuals problem-solving and decision-making skills;

- Does not advocate a particular viewpoint.

- Provides facts or opinions about environmental issues;

- Does not necessarily teach individuals critical thinking;

- Does not necessarily enhance individuals' problem-solving and decision-making skills

- $\quad$ May advocate a particular viewpoint.

Ecology has the following branches:

1. Content of ecology

2. Content of population ecology

3. Content of human ecology
4. What are the components of ecology?

1. Content of ecology- In ecology, ecosystems are composed of organisms, the communities they comprise, and the non-living aspects of their environment. The four main levels of study in ecology are the organism, population, community, and ecosystem. Ecosystem processes are those sustain and regulate the environment.

2. Content of population ecology- Populations consist all of the species living within a specific area, and populations fluctuate based on a number of factors: seasonal and yearly changes in the environment, natural disasters- such as forest fires and volcanic eruptions, and competition for resources between and within species.

- What does population ecology include? Population ecology is the study of these and other questions about what factors affect population and how and why a population changes over time.... . The study of population ecology includes understanding, explaining, and predicting species distributions.

- What is in example of population in ecology?

-in ecology, a population consists of all organisms of a particular species living in a given area. For instance, we could say that a population or humans lives in New York City, and that another population of humans living in Gross.

What are the three characteristics of population ecology?

What is the other name of population ecology?

What are the five characteristics of population ecologists study?

What are three examples of population?

What are the 3 patterns of population distribution?

What are called population process? 
CURRENT RESEARCH JOURNAL OF PEDAGOGICS 2(11): 71-75, November

2021 DOI: https://doi.org/10.37547/pedagogics-crjp-02-11-15

ISSN 2767-3278

(C)2021 Master Journals

\section{Crossref doi) 81 Google}

Accepted 25th November, 2021 \& Published 30 ${ }^{\text {th }}$ November, 2021

3. Content of human ecology- Human Ecology is the study of the interactions between man and nature in different cultures. Human ecology combines the ideas and methods from several disciplines, including anthropology, sociology, biology, economic history and archeology.

What are the three characteristics of population ecology?

From an ecological view point there are three

These are, pre-reproductive, reproductive and past reproductive. The relative duration of these age groups in proportion to the life span varies greatly

with different organisms.

Summary- Within this article it has been given the most primitive notion about ecology, environment, its meaning, content and some instructions about teaching ecology.

Earlier, millions and billions centuries ago the planet was pure, natural and clean. When human beings appeared on the planet, they began to influence the nature little by little and the earth began to suffer from different changes and interferences.

Ecology- as it is explained today the real lifestyle of human beings. It is the daily activity of people in a real world.

Teachers create lesson plans and track those plans to the entire class, individually to students or in small groups, track student progress and present the information to parents, create tests, create and reinforce classroom rules, work with school administration prepare students for standardized tests, and manage to gain the lesson plan goals.

The teachers of ecology subject and trainers of ecological sciences have to give very simple examples in order the pupils, students and those who are responsible to preserve the environment of our surroundings as it has been given within this article.

The teachers have to choose the modern innovative pedagogical technologies in teaching process. There are many ways and different methods of teaching this subject. At the result of teaching process the teachers should gain the goals. It is also important that teachers have to give the meanings of ecological terms and their contents in a definite state and situations.

\section{REFERENCES}

1. "Method", Merriam-Webster.com. Dictionary, Merriam-Webster, https: II www Merriam. Webster.com| dictionary | method.

2. Krupka, J.J. $\{2000\}$. The importance of naturalists as teachers and the use of natural history as a teaching tool. The American Biology Teacher, 62(8), 553-558.

3. Liberman, G. and Hoody, L.(1998). Closing the Achievement Gap. Using the Environment as an Integrative Context in Learning. Poway, CA: State Education and Environment Roundtable, Science Wizards.

4. Newmann, F., Marks, $\mathrm{H}$ \& Gamoran, A. (1966). Authentic pedagogy and student performance. American Journal of Education, 104, 280-302.

5. Schulman, L. (1987). Knowledge and teaching: Foundations of the new reform. Harvard Educational Review, 57 (1), 1-22.

6. Matic', V. (2012). Environmental Education of Students in Vocational Schools in a Multimedia Surrounding, IEEE 35 th international convention, Opatija.

7. R. C. Clark, R. Mayer (2001). E. Learning and Science of Instruction, San Francisco, Preiffer. 
CURRENT RESEARCH JOURNAL OF PEDAGOGICS 2(11): 71-75, November

2021 DOI: https://doi.org/10.37547/pedagogics-crjp-02-11-15

ISSN 2767-3278

(C)2021 Master Journals

Crossref dof 81 Google

Accepted 25th November, 2021 \& Published 30th November, 2021

8. M. Dresner, A. Moldenke. Authentic field ecology experiences for teachers. American Biology Teacher. Vol. 64 (8). 2002. Pp. 659663.

9. Darling-Hammond, L. (1996). The right to learn and the advancement of teaching. Research, policy and practice for democratic education. Educational Research, 25(6), 5-17.

10. Goodland, J. (1990). Teachers for Our Nation's Schools. San Fransisco: JosseyBass. 